Indexed by

\title{
OPTIMIZATION MODELLING OF ENGINEERING
Scopus
ENTERPRISES FINANCIAL SECURITY IMPROVEMENT
}

Crossref

KOBSON

Foogle

\section{Kateryna Oriekhova}

V. N. Karazin Kharkiv National University, Educational and scienti ic institute "Karazin Banking Institute", Department of Banking and Finan-cial Technologies, Kharkiv, Ukraine

\section{Olesia Solodovnik}

O.M. Beketov Kharkiv National University of Urban Economy, Financial and Economic Security, Accounting and Auditing Department, Kharkiv, Ukraine

\section{Oleksander Kendiukhov \\ Zaporizhzhya National University, Department of Human Resources and Marketing, Zaporizhzhya, Ukraine}

\section{Liudmyla Zakharkina \\ Sumy State University, Department of Finance and Entrepreneurship, Sumy, Ukraine}

\author{
Oleksii Zakharkin \\ Sumy State University, \\ Department of Finance and \\ Entrepreneurship, Sumy, \\ Ukraine
}

\section{Tetiana Murovana \\ Taras Shevchenko National University of Kyiv, Department of Environmental Management and Entrepreneurship, Kyiv, Ukraine}

Key words: engineering enterprises, optimization modeling, financial security, methodical approach, net profit

doi:10.5937/jaes0-30842

Cite article:

Oriekhova K., Kendiukhov., Zakharkin O., Solodovnik O., Zakharkina L., Murona T. (2021) OPTIMIZATION MODELLING OF ENGINEERING ENTERPRISES FINANCIAL SECURITY IMPROVEMENT, Journal of Applied Engineering Science, 19(4), 1065 - 1073, DOI:10.5937/ jaes0-30842

Online aceess of full paper is available at: www.engineeringscience.rs/browse-issues 


\title{
OPTIMIZATION MODELLING OF ENGINEERING ENTERPRISES FINANCIAL SECURITY IMPROVEMENT
}

\author{
Kateryna Oriekhova', Oleksander Kendiukhov' ${ }^{2}$ Oleksii Zakharkin ${ }^{3}$, Olesia Solodovnik ${ }^{4 *}$, \\ Liudmyla Zakharkina ${ }^{3}$, Tetiana Murovana ${ }^{5}$ \\ ${ }^{1}$ V. N. Karazin Kharkiv National University, Educational and scientific institute "Karazin Banking Institute", \\ Department of Banking and Financial Technologies, Kharkiv, Ukraine \\ ${ }^{2} Z a p o r i z h z h y a$ National University, Department of Human Resources and Marketing, Zaporizhzhya, Ukraine \\ ${ }^{3}$ Sumy State University, Department of Finance and Entrepreneurship, Sumy, Ukraine \\ ${ }^{4}$ O.M. Beketov Kharkiv National University of Urban Economy, Financial and Economic Security, \\ Accounting and Auditing Department, Kharkiv, Ukraine \\ ${ }^{5}$ Taras Shevchenko National University of Kyiv, Department of Environmental Management and \\ Entrepreneurship, Kyiv, Ukraine
}

The article's purpose is to develop a methodical approach to improving financial security, which takes into account the acceleration of reproducing processes on Ukraine's device of engineering enterprises. This approach is based on multi-cellular vector optimization. It allows us to determine the optimal values of current assets' manifestations and net profit dynamics and set the optimal correlation between them. Approbation of a methodical approach to improving financial security and acceleration of reproducing processes on the example of Ukraine's four engineering enterprises was performed. Financial statement data for eight periods were used to build optimization vectors. To improve financial security and accelerate the reproducing processes of Ukraine's engineering enterprises, certain volumes of working assets, periods of their turnover, their marginal value taking into account different financing sources, and maximum net profit at certain manifestations of the dynamics of current assets are established. In implementing the methodical approach to improving financial security and accelerating the reproducing processes in engineering enterprises' practical activities, highly qualified personnel occupy a significant role and place. The powerful toolkit of their provision is material stimulation (an increase of wages, provision of premiums) and establishment of relations in the team (social justice in the department); the opportunity to advance on the career ladder; respect for employees by management; frank and friendly relationships at all levels of management; participation in corporate holidays of all employees. Therefore, the study's further direction is developing a methodical approach to improving the financial security of engineering enterprises, taking into account personnel support.

Key words: engineering enterprises, optimization modeling, financial security, methodical approach, net profit

\section{INTRODUCTION}

Mechanical engineering is one of the system-forming branches of the national economy in terms of production and sales. Because engineering provides means of production of other sectors of the economy (fuel, agro-industrial, construction), thereby contributing to the renewal and accumulation of capital [1]. Ukraine's engineering complex includes more than 20 industries, 58 sub-sectors, which employs 11,267 enterprises (146 large, 1834 medium, 9287 small), which employs about 1.5 million. Despite the significant contribution of engineering to the development of Ukraine's national economy, it should be noted that its share in the structure of industry for 20132019 decreased by $0.8 \%$ [2]. There is a decrease in financial security and slowing of reproducible processes at Ukraine's engineering enterprises, because of the use of outdated equipment and equipment, lack of longterm sources of financing of working assets, low level of innovation activity and investment attractiveness; low competitiveness of products; insufficient number of highly qualified personnel. Financial security and reproduc- ing processes depend largely on the improvement of working asset management due to their movement in the spheres of production and sale of products [3] and [4]. Profit is one of the primary sources of their financial resources, which are used for the expanded reproduction of engineering enterprises' activities. In these circumstances, the transition from traditional management of certain elements of working assets to managing their consistent change, i.e., current assets' movement, becomes relevant [5], [6] and [7]. The article's purpose is to develop a methodical approach to improving financial security, taking into account the acceleration of reproducing processes on Ukraine's device of engineering enterprises [8].

\section{THEORETICAL BACKGROUND}

Financial security and reproducing processes of engineering enterprises of Ukraine depend on the impact of manifestations of the dynamics of current assets: changes in the number of current assets and each of their el- 
ements: changes in the number of current assets and each element $\left(R_{d}\right)$; changes in the proportion of each element in their sum $\left(R_{s}\right)$; changes in the period of turnover of current assets and their elements $\left(R_{c}\right)$; financing of elements of current assets from various sources $\left(R_{\text {fin }}\right)$ [9] and [10].

Each of these manifestations of dynamics has its unit of measurement. Thus, the change in the number of current assets is measured in currencies because it indicates the number of funds invested in this element of current assets at each point in time, change of share - as a percentage of the total amount of current assets, change of turnover period - in days. In the fourth manifestation of the dynamics, the financing of working assets' elements at the expense of own and borrowed funds is displayed. The unit of measurement of this manifestation of the dynamics is the cost of raising capital, that is, a percentage of the profits that the company will not receive. To minimize threats, it is necessary to optimize these manifestations of the dynamics of current assets.

In our opinion, there is a need to maintain optimal trends in such indicators to improve the financial security of engineering enterprises, taking into account the acceleration of reproducible processes. When optimizing the movement of current assets under which the trend $\left(R_{t 0}\right)$ can be excluded, since structural change characterizes not a quantitative, but qualitative change of current assets:

$\left\{\begin{array}{l}\text { Profit } \rightarrow \text { max } \\ R_{d} \rightarrow \text { min } \\ R_{s} \rightarrow \text { min } \\ R_{c} \rightarrow \text { min } \\ R_{\text {fin }} \rightarrow \text { min }\end{array}\right.$

Suppose the trends given in formula (1) are preserved. In that case, the probability of dynamic, structural, cyclical (flow), and percentage changes in the movement of current assets at engineering enterprises will be minimal [11] and [12], and the corresponding value of the function will determine the volume of a particular element of current assets at a specific date and the optimal size of its hedge [13] and [14]. The most effective will be the management of current assets, which will maximize net income and minimize the volume of current assets, their period of circulation, and value.

Depending on the time, the manifestations of the dynamics of Ukraine's current assets of engineering enterprises change their value. Based on this, we determine the mathematical dependence (i.e., function) of changes in the manifestations of dynamics at the time of observation [15]. Since it is virtually impossible to determine the functions by the values of the manifestations of current assets' dynamics, it is advisable to use an approximate trend calculated using trend lines. It is advisable to use parabolic trends as optimization models because they have only one optimal criterion - the function's extremum. These functions indicate the approximate trends and direction of change in the dynamics of current assets over time.
Thus, these functions will determine the approximate volume of current assets, the period of their circulation and value, as well as net income at a specific date.

\section{RESULTS}

The activity of Ukraine's engineering enterprises was chosen to test the methodological approach to improving financial security, taking into account the acceleration of reproduction processes [16]. Financial reporting data for eight periods were used to construct optimization vectors. The calculation of the functions of the manifestations of the dynamics of current assets and the function of changing the net profit of engineering enterprises of Ukraine was carried out using Microsoft Excel. In Fig. 1-4 presents the calculation of the functions of the manifestations of the dynamics of current assets and the function of changes in net profit on the example of four engineering enterprises of Ukraine. As we can see from Fig. 1-4 shows the corresponding functions and calculated values of the probability of approximation $\left(R^{2}\right)$, which indicate a close relationship between real and trend data in most manifestations of dynamics and confirm the reliability of the use of these functions for further calculation.
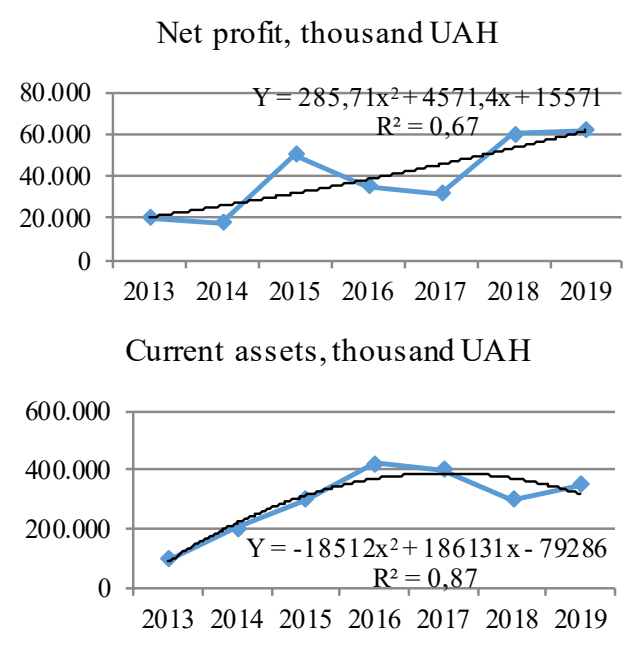

Turnover period of current assets, days

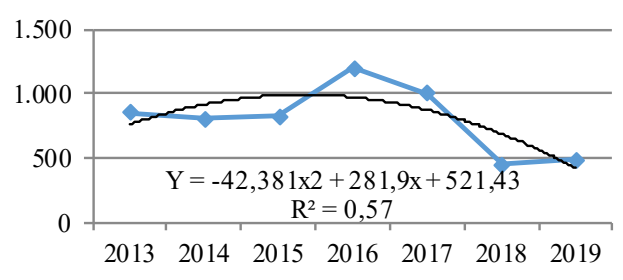

The cost of funding sources for current as sets, $\%$

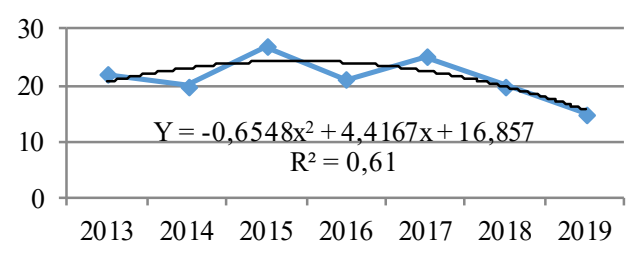

Figure 1: Calculation of the functions of financial security indicators of PJSC "Kharkiv Engineering Plant "Svitlo Shakhtarya"

Istraživanja i projektovanja za privredu ISSN 1451-4117 Journal of Applied Engineering Science Vol. 19, No. 4, 2021 
Net Profit, thousand UAH

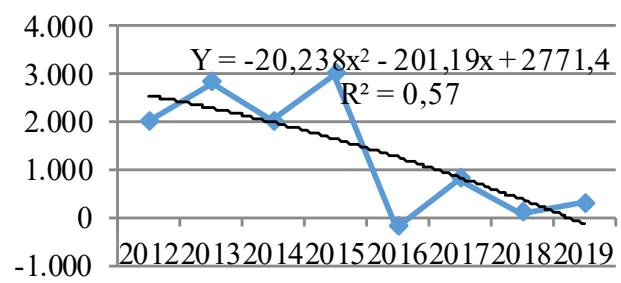

Turnover period of current assets, days

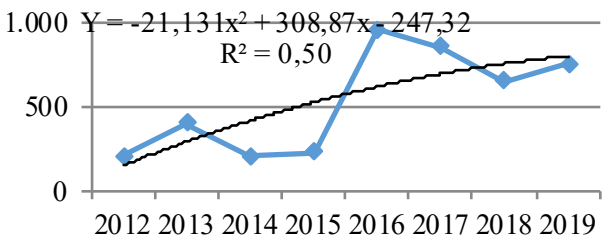

Current as sets, thousand UAH

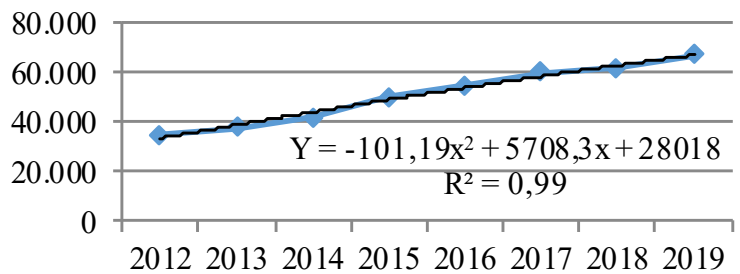

The cost of funding sources for current assets, $\%$

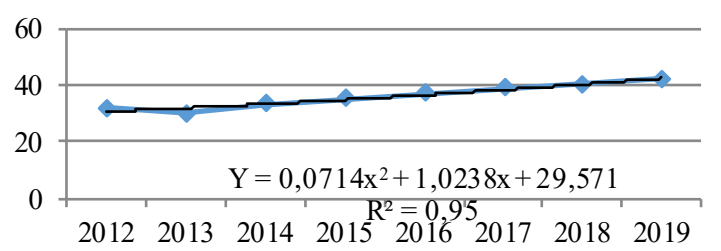

Figure 2: Calculation of the functions of financial security indicators of PJSC "Kharkiv Engineering Plant "PLINFA"

Net Profit, thousand UAH

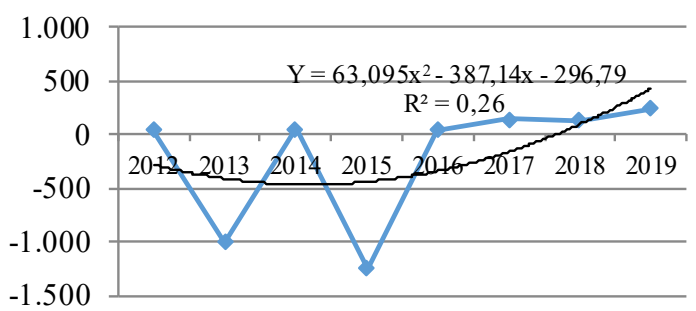

The cost of funding sources for current ass ets, $\%$

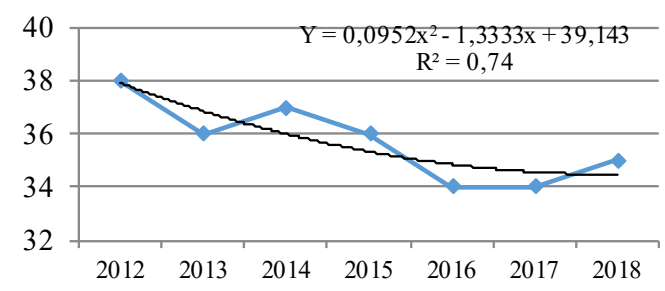

Current assets, thous and UAH

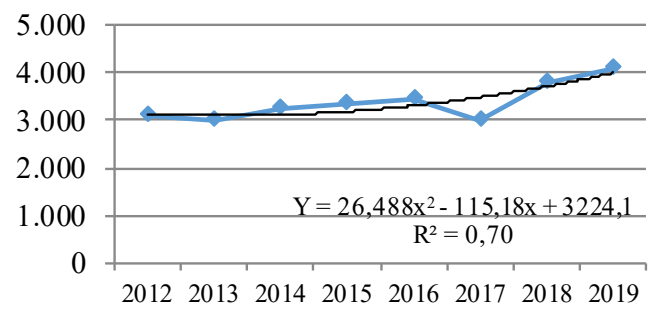

Turnover period of current as sets, days

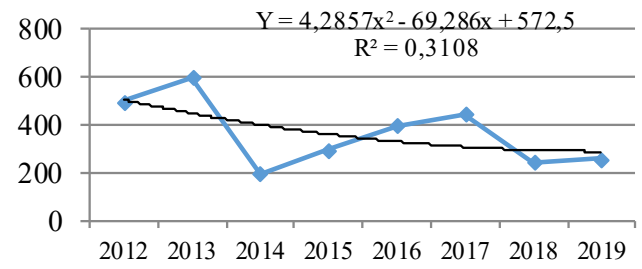

Figure 3: Calculation of the functions of financial security indicators of PJSC "Kupyansk Engineering Plant"

Net Profit, thousand UAH

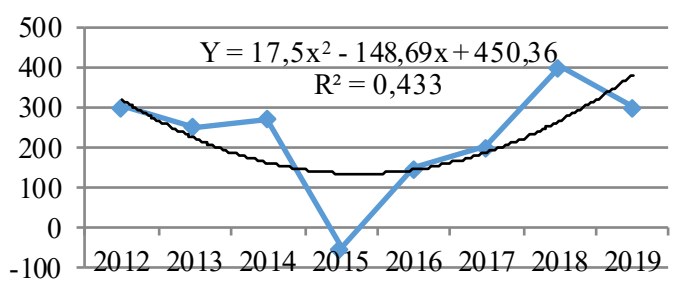

The cost of funding sources for current assets, $\%$

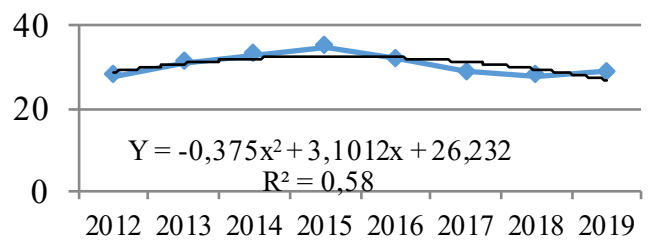

Current assets, thousand UAH

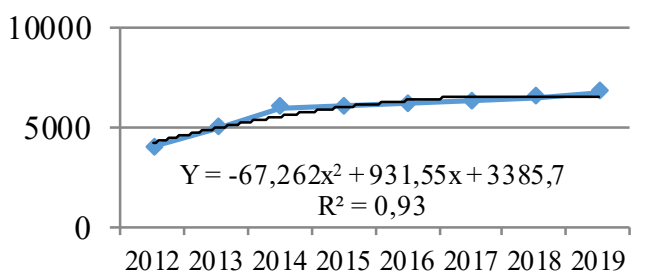

Turnover period of current assets, days

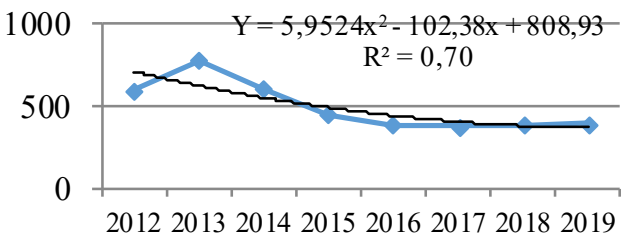

Figure 4: Calculation of the functions of financial security indicators of PJSC "Drohobych Engineering Plant" 
Since each of these functions has its optimum, and the definition of a single preferred criterion is impossible, the problem can be solved only by the method of multicriteria (vector) optimization [21]. The need for multicriteria optimization arises when necessary to make a decision, the quality of which is assessed by several, sometimes contradictory criteria [22]. In general, multicriteria optimization can be represented by a particular function - a vector criterion:

$R(x)=\left(R_{1}(x), R_{2}(x), \ldots, R_{n}(x)\right)$

where $R_{1}, R_{2}, \ldots, R_{n}$ - a set of objective functions, which are called partial optimality criteria;

$x$ - a set of values that are the solution of objective functions.

If there are several partial criteria, multicriteria optimization is considered as a problem of finding such a value of $\mathrm{x}$, which provides at the same time the minimum value of each partial criterion of optimality:

$\min _{1}(x) * \min R_{2}(x) * \ldots * \min R_{n}(x)$

In the case of dominance of one of the others' criteria, there is a single point $x^{*}$, in which all partial criteria are consistent with each other. Such a point $x^{*}$ is called the optimal solution, and the values of all partial criteria are minimal in it [23] and [24].

It is also possible that the partial criteria are contradictory, and the minimum for each of them is reached at different points. In this case, a decrease in one partial criterion leads to an increase in other partial criteria. Such points $x_{i}^{0}$, at which the principle of dominance over any point $x$ is not fulfilled, is called effective. At effective points, the generalized optimality criterion $R(x)$ does not decrease for all partial criteria simultaneously. The set of vector criteria $R(x)$, which corresponds to the set of all effective points, is called the field of compromises, and the set of effective points itself is called the field of solutions optimal for Pareto [25], [26] and [27]. It causes a compromise between the partial optimality criteria to decide which of $\operatorname{Ri}(x)$ values in the field of compromises are more appropriate.

Given the need to reduce all the criteria presented in formula (4) to a single trend, the net profit function Net Profit $\rightarrow$ max should be replaced by the reverse $1 /$ Net Profit $\rightarrow$ min. In this case, the function (3) to increase financial security, taking into account the reproduction processes, will be as follows:

$$
\left\{\begin{array}{l}
\min _{d}(x) \\
\min _{c}(x) \\
\min R_{f i n}(x) \\
\min \frac{1}{N P}(x) \\
R_{i}(x)>0
\end{array}\right.
$$

Its generalized vector criterion will look like:

$R(x)=\left(R_{d}(x), R_{c}(x), R_{\text {fin }}(x), \frac{1}{N P}(x)\right)$

In this case, multicriteria optimization will determine such a point in time $x^{*}$. All the trends defined in formula (4) will be fulfilled, i.e., the management of current assets will be optimal. To generalize the vector criterion of the functions of current assets and net profit should use a multiplicative criterion of optimality, calculated by the formula (6):

$\min F(w, R(x))=\min \prod \prod_{i=1}^{n} R_{i}^{\left(w_{i}\right)}(x)$

where $w_{i}$ - weights;

$x_{i}>0$;

$\prod_{i=1}^{n} w_{i}=0$.

It is appropriate if a significant role is played by applying absolute values of partial optimality criteria with a parameter $\mathrm{x}$. In this case, the solution to finding the minimum value of each partial criterion of optimality $\min R_{d}(x), \min R_{c}(x)$, $\min R_{\text {fin }}(x), \min 1 / \operatorname{Pr}(x)$ can be reduced to minimize the multiplicative function.

Weights $w_{i}$ can be determined using expert assessments or statistical modeling. To prevent subjectivity in selecting weights, it is advisable to select them according to the degree of significance of the partial criteria of optimality. To do this, for each partial criterion of optimality $R_{i}$, $i=1,2, \ldots, n$ the coefficient of relative scatter is calculated:

$\delta_{i}=\frac{R_{i}^{+}-R_{i}^{-}}{R_{i}^{+}}=1-\frac{R_{i}^{-}}{R_{i}^{+}}$

where $R_{i}^{-}=\min R_{i}(x)$;

$\mathrm{R}_{\mathrm{i}}^{+}=\max _{\mathrm{i}}(\mathrm{x})$.

It determines the maximum possible deviation by the i-th partial criterion. The weights $w_{i}$ are most important for those criteria whose relative variance is more significant:

$w_{i}=\frac{\delta_{i}}{\prod_{i=1}^{n} \delta_{i}}$

In table 1 shows the results of calculations of weights of financial security of engineering enterprises of Ukraine.

According to the calculated weights of financial security indicators, generalized scalar functions $F$ for engineering enterprises of Ukraine are obtained, which are presented in table 2.

To find the optimal solution of multicriteria optimization $\left(x^{*}\right)$ to increase the financial security of engineering enterprises of Ukraine, it is expedient to find the extremum of the scalar function $\mathrm{F}$ and solve the equation of this kind:

$F^{\prime}(x)=0, \quad x^{*}=\operatorname{argextr} F(x)$

Its decision determines the ordinal number of the period from the date of observation, in which certain trends will reach the optimal state, ie, the following conditions will be met: maximization of net profit and minimization of current assets, their turnover period, the value of cur- 
Table 1: The results of calculations of weights of financial security of engineering enterprises of Ukraine

\begin{tabular}{|c|c|c|c|c|c|c|c|c|c|}
\hline \multicolumn{5}{|c|}{ PJSC "Kharkiv Engineering Plant "Svitlo Shakhtarya" } & \multicolumn{5}{|c|}{ PJSC Kharkiv Engineering Plant "PLINFA" } \\
\hline & $\mathrm{R}_{\mathrm{i}}^{+}$ & $\mathrm{R}_{\mathrm{i}}^{-}$ & $\delta_{i}$ & $w_{i}$ & & $\mathrm{R}_{\mathrm{i}}^{+}$ & $\mathrm{R}_{\mathrm{i}}^{-}$ & $\delta_{i}$ & $w_{i}$ \\
\hline $1 / \mathrm{NP}$ & 1,02 & $-1,54$ & 2,51 & 0,07 & $1 / \mathrm{NP}$ & 0,80 & $-0,83$ & 2,04 & 0,08 \\
\hline $\mathrm{R}_{\mathrm{d}}$ & 0,84 & $-1,84$ & 3,20 & 0,09 & $\mathrm{R}_{\mathrm{d}}$ & 1,36 & $-1,48$ & 2,09 & 0,08 \\
\hline $\mathrm{R}_{\mathrm{c}}$ & 0,66 & $-1,36$ & 3,05 & 0,09 & $R_{c}$ & 0,67 & $-1,32$ & 2,95 & 0,11 \\
\hline$R_{\text {fin }}$ & 1,62 & $-0,70$ & 1,43 & 0,04 & $R_{\text {fin }}$ & 1,08 & $-1,17$ & 2,08 & 0,08 \\
\hline $\operatorname{Pr}$ & & & 35,12 & 0 & $\operatorname{Pr}$ & & & 26,25 & 0 \\
\hline \multicolumn{5}{|c|}{ PJSC "Kupyansk Engineering Plant" } & \multicolumn{5}{|c|}{ PJSC "Drohobych Engineering Plant" } \\
\hline & $\mathrm{R}_{\mathrm{i}}^{+}$ & $\mathrm{R}_{\mathrm{i}}^{-}$ & $\delta_{i}$ & $w_{i}$ & & $\mathrm{R}_{\mathrm{i}}^{+}$ & $\mathrm{R}_{\mathrm{i}}^{-}$ & $\delta_{i}$ & $w_{i}$ \\
\hline $1 / \mathrm{NP}$ & 1,20 & $-1,47$ & 2,23 & 0,21 & $1 / \mathrm{NP}$ & 1,30 & $-1,08$ & 1,83 & 0,08 \\
\hline$R_{d}$ & 1,70 & $-0,73$ & 1,43 & 0,14 & $R_{-d}$ & 0,87 & $-1,70$ & 2,96 & 0,13 \\
\hline $\mathrm{R}_{\mathrm{c}}$ & 0,93 & $-0,63$ & 1,68 & 0,16 & $\mathrm{R}_{\mathrm{c}}$ & 1,09 & $-1,32$ & 2,22 & 0,10 \\
\hline$R_{\text {fin }}$ & 1,40 & $-1,33$ & 1,95 & 0,19 & Rfin & 1,06 & $-0,99$ & 1,94 & 0,08 \\
\hline $\mathrm{Pr}$ & & & 10,36 & 0 & $\mathrm{Pr}$ & & & 23,28 & 0 \\
\hline
\end{tabular}

Table 2: Generalized scalar functions F increasing the financial security of engineering enterprises of Ukraine

\begin{tabular}{|c|c|}
\hline Enterprise & Generalized scalar functions $\mathrm{F}$ \\
\hline PJSC "Kharkiv Engineering Plant "Svitlo Shakhtarya" & $\begin{array}{c}F(x)=\left(285,17^{*} x^{2}+4571,4^{*} x+15571\right)^{*} 0,07^{*} \\
*\left(-18512^{*} x^{2}+186131^{*} x-79286\right)^{*} 0,09^{*} \\
*\left(-42,38^{*} x^{2}+281,90^{*} x+521,43\right)^{*} 0,09^{*} \\
*\left(-0,6548^{*} x^{2}+4,42^{*} x+16,86\right)^{*} 0,04\end{array}$ \\
\hline PJSC Kharkiv Engineering Plant "PLINFA" & $\begin{array}{c}F(x)=\left(-20,24 * x^{*}-201,19^{*} x+2771,4\right)^{*} 0,08^{*} \\
*\left(-101,19^{*} x^{2}+5708,3^{*} x+28018\right)^{*} 0,08^{*} \\
*\left(-21,13^{*} x^{2}+308,87^{*} x-247,32\right)^{*} 0,11^{*} \\
*\left(0,07^{*} x^{2}+1,02^{*} x+29,57\right)^{*} 0,08\end{array}$ \\
\hline PJSC "Kupyansk Engineering Plant" & $\begin{array}{c}\mathrm{F}(\mathrm{x})=\left(63,10^{*} \mathrm{x}^{2}-387,14^{*} \mathrm{x}-296,79\right)^{*} 0,21^{*} \\
{ }^{*}\left(26,49^{*} \mathrm{x}^{2}-115,18^{*} \mathrm{x}+3224,1\right)^{*} 0,14^{*} \\
\quad *\left(0,10^{*} \mathrm{x}^{2}-1,33^{*} \mathrm{x}+39,14\right)^{*} 0,16^{*} \\
{ }^{*}\left(4,29^{*} x^{2}-69,29^{*} x+572,5\right)^{*} 0,19\end{array}$ \\
\hline PJSC "Drohobych Engineering Plant" & $\begin{array}{c}\mathrm{F}(\mathrm{x})=\left(17,5^{*} \mathrm{x}^{2}-148,69^{*} \mathrm{x}+450,36\right)^{*} 0,08^{*} \\
{ }^{*}\left(-67,26^{*} \mathrm{x}^{2}+931,55^{*} \mathrm{x}+3385,7\right)^{*} 0,13^{*} \\
{ }^{*}\left(-0,375^{*} x^{2}+3,10^{*} x+26,23\right)^{*} 0,10^{*} \\
{ }^{*}\left(5,95^{*} x^{2}-102,38^{*} x+808,93\right)^{*} 0,08\end{array}$ \\
\hline
\end{tabular}

rent assets of engineering enterprises of Ukraine. Calculations of the multicriteria optimization problem were performed using a software package Mathcad. They testified to the absence of a single optimal solution $x^{*}$ at each of Ukraine's engineering enterprises. Instead, seven effective points $x_{i}^{0}$ were obtained for each enterprise
(Pareto-optimal solutions). The results of such calculations are presented in table 3.

Thus, the calculations' results indicate the absence of a single point in time from the beginning of observations for each engineering enterprise of Ukraine, when certain optimal trends were observed. It is determined that there

Table 3: Optimal Pareto solutions of the problem of multicriteria optimization of financial security engineering enterprises of Ukraine

\begin{tabular}{|c|c|c|c|c|c|c|c|}
\hline Enterprise & $\mathrm{x}_{1}{ }^{0}$ & $\mathrm{x}_{2}{ }^{0}$ & $\mathrm{x}_{3}{ }^{0}$ & $\mathrm{x}_{4}{ }^{0}$ & $\mathrm{x}_{5}{ }^{0}$ & $\mathrm{x}_{6}{ }^{0}$ & $\mathrm{x}_{7}{ }^{0}$ \\
\hline PJSC "Kharkiv Engineering Plant "Svitlo Shakhtarya" & $-3,80$ & 0,39 & 1,90 & 3,43 & 4,70 & 5,28 & 6,82 \\
\hline PJSC Kharkiv Engineering Plant "PLINFA" & $-30,17$ & $-3,97$ & 4,02 & 4,42 & 9,43 & 43,47 & 103,69 \\
\hline PJSC "Kupyansk Engineering Plant" & $-13,06$ & $-3,07$ & 1,53 & 4,35 & 5,37 & 13,25 & 59,57 \\
\hline PJSC "Drohobych Engineering Plant" & $-42,97$ & $-10,17$ & 3,47 & 3,91 & 4,17 & 8,62 & 19,83 \\
\hline
\end{tabular}


Table 4: Optimal values of financial security indicators of engineering enterprises of Ukraine

\begin{tabular}{|c|c|c|c|c|}
\hline Indicator & $\mathrm{x}_{1}^{0}$ & $\mathrm{x}_{2}^{0}$ & $\mathrm{x}_{3}{ }^{0}$ & $\mathrm{x}_{4}^{0}$ \\
\hline \multicolumn{5}{|c|}{ PJSC "Kharkiv Engineering Plant "Svitlo Shakhtarya" } \\
\hline$x_{i}^{0}$ & $-3,8$ & 0,39 & 1,9 & 3,43 \\
\hline Pr, thousand UAH & 35646,56 & 12017,66 & 19084,35 & 34665,17 \\
\hline $\mathrm{R}_{\mathrm{d}}$, thousand UAH & $-1236825,84$ & $-49255,77$ & 196934,49 & 348147,56 \\
\hline $\mathrm{R}_{\mathrm{c}}$, days & $-1130,36$ & 633,58 & 913,79 & 1005,61 \\
\hline $\mathrm{R}_{\mathrm{fin}}, \%$ & 55,61 & 12,73 & 7,87 & 8,66 \\
\hline Indicator & $\mathrm{x}_{5}^{0}$ & $\mathrm{x}_{6}^{0}$ & $\mathrm{x}_{7}^{0}$ & \\
\hline$x_{i}^{0}$ & 4,7 & 5,28 & 6,82 & \\
\hline Pr, thousand UAH & 54036,05 & 64825,16 & 99382,68 & \\
\hline $\mathrm{R}_{\mathrm{d}}$, thousand UAH & 398558,01 & 398917,27 & 330915,34 & \\
\hline $\mathrm{R}_{\text {с }}$, дні & 934,97 & 858,39 & 520,21 & \\
\hline $\mathrm{R}_{\mathrm{fin}}, \%$ & 13,69 & 17,31 & 30,93 & \\
\hline \multicolumn{5}{|c|}{ PJSC Kharkiv Engineering Plant "PLINFA" } \\
\hline$x_{i}^{0}$ & $-30,17$ & $-3,97$ & 4,02 & 4,42 \\
\hline Pr, thousand UAH & 21920,30 & 7252,91 & 3758,80 & 3595,90 \\
\hline $\mathrm{R}_{\mathrm{d}}$, thousand UAH & $-230830,34$ & 4679,91 & 48831,33 & 50701,74 \\
\hline $\mathrm{R}_{\mathrm{c}}$, дні & $-30628,93$ & $-2042,04$ & 633,45 & 693,16 \\
\hline $\mathrm{R}_{\mathrm{fin}}, \%$ & 26,60 & 20,34 & 9,74 & 9,10 \\
\hline$x_{i}^{0}$ & 9,43 & 43,47 & 103,69 & \\
\hline $\mathrm{Pr}$, thousand UAH & 1652,71 & $-6786,94$ & $-1377,47$ & \\
\hline $\mathrm{R}_{\mathrm{d}}$, thousand $\mathrm{UAH}$ & 71383,18 & 77260,50 & $-487298,17$ & \\
\hline $\mathrm{R}_{\mathrm{c}}$, дні & 841,51 & $-27552,45$ & $-203338,96$ & \\
\hline $\mathbf{R}_{\mathrm{fi}}, \%$ & 0,26 & $-102,10$ & $-463,68$ & \\
\hline \multicolumn{5}{|c|}{ PJSC "Kupyansk Engineering Plant" } \\
\hline $\mathrm{x}_{\mathrm{i}}^{0}$ & $-13,06$ & $-3,07$ & 1,53 & 4,35 \\
\hline $\mathrm{Pr}$, thousand UAH & $-87,24$ & $-228,61$ & $-117,50$ & 5,56 \\
\hline $\mathrm{R}_{\mathrm{d}}$, thousand UAH & 13416,88 & 4553,80 & 3155,79 & 3135,26 \\
\hline $\mathrm{R}_{c}$, дні & 2177,88 & 824,24 & 458,50 & 314,59 \\
\hline $\mathrm{R}_{\mathrm{fin}}, \%$ & $-19,44$ & $-9,40$ & $-3,32$ & 0,85 \\
\hline $\mathrm{x}_{\mathrm{i}}^{0}$ & 5,37 & 13,25 & 59,57 & \\
\hline $\mathrm{Pr}$, thousand UAH & 60,35 & 667,80 & 10830,19 & \\
\hline $\mathrm{R}_{\mathrm{d}}$, thousand UAH & 3284,42 & 7240,50 & 130861,54 & \\
\hline $\mathrm{R}_{\mathrm{c}}$, дні & 277,57 & 260,70 & 9796,29 & \\
\hline $\mathrm{R}_{\mathrm{fin}}, \%$ & 2,45 & 16,28 & 151,85 & \\
\hline \multicolumn{5}{|c|}{ PJSC "Drohobych Engineering Plant" } \\
\hline $\mathrm{x}_{\mathrm{i}}^{0}$ & $-42,97$ & $-10,17$ & 3,47 & 3,91 \\
\hline $\mathrm{Pr}$, thousand UAH & $-64679,13$ & $-8496,37$ & 1190,16 & 1368,87 \\
\hline $\mathrm{R}_{\mathrm{d}}$, thousand UAH & $-190228,13$ & $-15502,14$ & 6238,47 & 6441,77 \\
\hline $\mathrm{R}_{c}$, дні & $-4732,08$ & 649,67 & 540,98 & 514,52 \\
\hline $\mathrm{R}_{\mathrm{fin}}, \%$ & $-3,97$ & $-25,21$ & 20,11 & 22,10 \\
\hline $\mathrm{x}_{\mathrm{i}}^{0}$ & 4,17 & 8,62 & 19,83 & \\
\hline Pr, thousand UAH & 1470,53 & 2758,04 & 2210,97 & \\
\hline $\mathrm{R}_{\mathrm{d}}$, thousand UAH & 6547,28 & 6668,15 & $-7139,00$ & \\
\hline $\mathrm{R}_{c}$, дні & 498,22 & 141,44 & $-1407,65$ & \\
\hline $\mathrm{R}_{\mathrm{fin}}, \%$ & 23,29 & 45,50 & 116,44 & \\
\hline
\end{tabular}


Table 5: Establishing a compromise on the identified contradictory trends to improve the financial security of engineering enterprises of Ukraine

\begin{tabular}{|c|c|c|c|c|c|}
\hline \multirow{2}{*}{ Enterprise } & \multicolumn{4}{|c|}{ The current trend } & \multirow{2}{*}{$\begin{array}{l}\text { Compromise } \\
\text { solution }\end{array}$} \\
\hline & $\operatorname{Pr}$ & $R_{d}$ & $\mathrm{R}_{\mathrm{c}}$ & $\mathrm{R}_{\mathrm{fin}}$ & \\
\hline PJSC "Kharkiv Engineering Plant "Svitlo Shakhtarya" & $\max$ & $\max$ & $\min$ & $\max$ & $x_{7}^{0}$ \\
\hline PJSC Kharkiv Engineering Plant "PLINFA" & $\min$ & $\max$ & $\max$ & $\min$ & $\mathrm{x}_{3}{ }^{0}$ \\
\hline PJSC "Kupyansk Engineering Plant" & $\max$ & $\max$ & $\max$ & $\max$ & $x_{6}{ }^{0}$ \\
\hline PJSC "Drohobych Engineering Plant" & $\max$ & $\max$ & $\min$ & $\max$ & $x_{6}^{0}$ \\
\hline
\end{tabular}

are seven moments for each engineering enterprise of Ukraine when most of the indicated tendencies are fulfilled. Based on the obtained optimal Pareto solutions $\left(x_{i}^{0}\right)$ for each engineering enterprise of Ukraine, it is possible to determine the approximate dates when the trends in the dynamics of current assets and standardized net profit were or will be optimal while maintaining the existing dynamics of the studied indicators. In table 4 presents the optimal values of financial security indicators of engineering enterprises of Ukraine.

Checking the obtained optimal values of financial security indicators of Ukraine's engineering enterprises allows us to reject some of the solutions optimal for Pareto because the obtained values of partial optimality criteria in these solutions do not meet the allowable requirements, for example, are negative. To choose the only optimal solution among those that satisfy the initial conditions, Ukraine's engineering enterprises need to make a decision based on a compromise between the studied indicators of the identified contradictory trends, i.e., making an optimal compromise solution of multicriteria optimization. Based on the results of this compromise, one Pareto-optimal solution is selected, which meets the two main requirements of increasing financial security out of four: maximizing net profit and minimizing the period of turnover of current assets of engineering enterprises of Ukraine. Table 5 shows the existing trends in the calculation of certain indicators and the serial number of the decision that meets the compromise requirements.

\section{CONCLUSION}

Thus, to increase financial security, taking into account the acceleration of reproduction processes, while maintaining existing trends, PJSC "Kupyansk Engineering Plant" should maintain the volume of current assets of 7 240.50 thousand $\mathrm{UAH}$, their turnover period is 261 days. At the same time, their value, taking into account different funding sources, should not exceed $16.28 \%$. Under such conditions, the net profit of PJSC "Kupyansk Engineering Plant" is 667.80 thousand UAH. To increase financial security, taking into account the acceleration of reproduction processes, while maintaining existing trends, PJSC Kharkiv Engineering Plant "PLINFA" must maintain current 48831.33 thousand $\mathrm{UAH}$, their value should not exceed $9.74 \%$, before the period of their circulation should be 633 days. The amount of net profit is 3758.80 thousand UAH. The optimal solution of the multicriteria optimization problem for PJSC "Kharkiv Engineering Plant" Svitlo Shakhtarya "necessitates maintaining current assets of 330915.34 thousand UAH, their value should not exceed $30.93 \%$, and the turnover period will be 520 days. The profit of PJSC "Kharkiv Engineering Plant" Svitlo Shakhtarya "should make 99 382,68 thousand UAH. For PJSC "Drohobych Engineering Plant" it is necessary to maintain the volume of current assets of 6668.15 thousand UAH. Their value should not exceed $45.40 \%$. The turnover period should be 141 days, and the amount of net profit is 2758.04 thousand UAH.

The methodical approach to increase financial security presented in the article considering the acceleration of the reproduction processes of engineering enterprises based on multicriteria vector optimization allows us to determine the optimal values of the dynamics of current assets and net profit and to establish the optimal ratio between them. In the implementation of the methodological approach to improving financial security, taking into account the reproduction processes in the practical activities of engineering enterprises, a significant role and place are occupied by highly qualified personnel. The decisive tools for their provision are material incentives (salary increases, bonuses) and the establishment of relationships in the team (social justice in the department); opportunity to move up the career ladder; respect for employees by management; open and friendly relations at all levels of government; participation in corporate holidays of all employees. Therefore, a further research area is to develop a methodological approach to improving the financial security of engineering enterprises, taking into account staffing.

\section{ACKNOWLEDGEMENTS}

This work was supported by the Ministry of Education and Science of Ukraine (Project No. 0117 U003922 «Innovative drivers of national economic security: structural modeling and forecasting»).

\section{REFERENCES}

1. Zakharkin, O., Basantsov, I., Myroshnychenko, lu. \& Shcherbachenko, V. (2019). Analysis of the innovative development directions for industrial enterprises, Espacios, 40 (27), 16-25. Retrieved from http://www. revistaespacios.com/a19v40n27/a19v40n27p16.pdf 
2. Statistical information. State Service Statistics: Official Web Resource. Retrieved from http://www. ukrstat.gov.ua (appeal date 23.04.2020).

3. Prokopenko, O.V., Domashenko, M.D., \& Shkola, V.Y. (2014). Management features of economic security in foreign economic activity of ukrainian engineering enterprises. Actual Problems of Economics, 160(1), 188-194.

4. Shpak, N., Kyrylych, T., \& Greblikaite, J. (2016). Diversification Models of Sales Activity for Steady Development of an Enterprise. Sustainability, 8 (4). DOI: 10.3390/su8040393.

5. Dźwigoł, H., Shcherbak, S., Semikina, M., Vinichenko, O., \& Vasiuta, V. (2019). Formation of Strategic Change Management System at an Enterprise. Academy of Strategic Management Journal, 18(SI1), 1-8. Retrieved from https://www.abacademies.org/articles/Formation-of-strategic-change-managementsystem-at-enterprise-1939-6104-18-SI-1-454.pdf

6. Vytvytska, O.D., Martynyuk, O.A., Shpak, N.O., Karcheva, G.T., Medynsky, I.P., \& Nodzhak, L.S. (2020). Modern Structural-functional modeling for the determination of the company's equilibrium conditions in the dynamic business environment. Mathematical Modeling and Computing, 7 (1), 104-111. DOI: 10.23939/mmc2020.01.104.

7. Binda, J., Prokopenko, M., Ramskyi, A., Shuplat, O., Halan, L., \& Mykhaylenko, D. (2020). Assessment of investment attractiveness of industrial enterprises. International Journal of Management, 11(2), 27-35. http://iaeme.com/MasterAdmin/Journal_uploads/ IJM/VOLUME_11_ISSUE_2/IJM_11_02_004.pdf

8. Ponomarenko, T.V., Prokopenko, O.V., Slatvinskyi, M.A., Biloshkurska, N.V., Biloshkurskyi, M.V., \& Omelyanenko, V.A. (2019). National Investment and Innovation Security Assessment Methodology. International Journal of Mechanical Engineering and Technology, 10 (2), pp. 847-857.

9. Gorovy, D.A. (2015). Financial instruments to minimize risks in the management of working capital. Problems and prospects of entrepreneurship development, 3 (1), 148-154. [in Ukrainian]

10. Getsov, P., Bo, W., Mardirossian, G. Nedkov, R., Stoyanov, S., Prokopenko, O., Boyanov, P. (2017). Equipment for evaluation of the characteristics of electronic-optic converters. Comptes Rendus de L'Academie Bulgare des Sciences, 70(11), pp. 15751578.

11. Morar, G.C. (2016). Factors influencing insolvency at the level of companies. Management Intercultural, 18 (2), 135-142.

12. Shmygol, N. (2014). Retrospective analysis of the united states experience in taxation, financial support to enterprises and its application for the formation of strategic objectives. Bulletin of Zaporizhia National University. Economic sciences, 1, 135-143.
13. Timchev, M. (2016). Accounting and balanced business analysis of the insolvency (bankruptcy) risk and of the company competitiveness in time of global economic crisis. Institute of Accounting, Control \& Analysis in the Globalization Circumstances, 2, 116-124.

14. Kwilinski, A., Dzwigol, H., \& Dementyev, V. (2020). Model of Entrepreneurship Financial Activity of the Transnational Company Based on Intellectual Technology. International Journal of Entrepreneurship, 24 (Special Issue: Entrepreneurship, Innovation Management and Sustainability), 1-5. Retrieved from https://www.abacademies.org/articles/Model-of-Entrepreneurship-Financial-Activity-of-the-Transnational-Company-Based-on-Intellectual-Technology. pdf

15. Miśkiewicz, R, \& Wolniak, R. (2020). Practical Application of the Industry 4.0 Concept in a Steel Company. Sustainability, 12(14), 5776. https://doi. org/10.3390/su12145776

16. Zakharkin, O., Basantsov, I., Shcherbachenko, V., \& Zakharkina, L. (2019). Public-private partnership as an effective tool in R\&amp;D activity. Proceedings of the 33rd International Business Information Management Association Conference, IBIMA 2019: Education Excellence and Innovation Management through Vision 2020, 6674-6678.

17. Financial statements of PJSC Kharkiv Engineering Plant "Svitlo Shakhtarya": official Web-resource. Retrieved from http://www.shaht.kharkov.ua/files/index_1.html. (appeal date 08/15/2019)

18. Financial statements of PJSC "Kharkiv Engineering Plant" PLINFA": official Web-resource. Retrieved from http://plinfa.com/ua/. (appeal date 08/25/2019)

19. Financial statements of PJSC "Kupyansk Engineering Plant": official Web-resource. Retrieved from https://ring.org.ua/edr/uk/company/00372307 (appeal date 09/17/2019)

20. Financial statements of PJSC "Drohobych Engineering Plant": official Web-resource. Retrieved from https://drohobych-rada.gov.ua (appeal date 10/23/2019)

21. Dugan Michael T., Medcalfe Simon K., \& Park Sang Hyun. (2018). A reconsideration of operating-financial leverage tradeoff hypothesis. Journal of financial economic policy. Vol. 10, No. 4. 473-483.

22. Moskalenko, N., Romanenko, O., \& Oliinyk, T. (2015). Approaches to enterprises' financial and economic security management. Economic journal -XXI, 7-8 (1), 54-57. 
23. Dyachenko, V.V. (2018).Pro Financial competitiveness as a component of financial security of the enterprise. Young scientist. № 11 (2), 1120-1123. [in Ukrainian]

24. Mayboroda, A.V. (2018). Financial security of the enterprise: theoretical features of its system and place in the structure of economic security. Bulletin of the University of Banking, 3, 58-65. [in Ukrainian]

25. Marina, A.S., Yelanskaya, N.O., \& Petrenko M.A. (2019). Financial rehabilitation in the system of financial and economic security of the enterprise. Business navigator, 2, 118-122. [in Ukrainian]

26. Melnyk, S.I. (2019). Financial security of the enterprise: the essence and modern problems of security. Problems of system approach in economy, 1 (2), 7-12. [in Ukrainian]
27. Mohamad, H., \& Evangelos, G. (2019). Financial institutions mergers: a strategy choice of wealth maximisation and economic value. Journal of financial economic policy. Vol.: ahead-of-print, No. ahead-ofprint. Retrieved from: 10.1108/JFEP-06-2019-0113.

28. Zhuravlyova I. V., \& Lelyuk S. V. (2014). Management of enterprise financial security and its intellectual component based on creating multiagent decision support system. Actual Problems of Economics, 7, 163-170. 